\title{
Utilization of Medicinal Plants In The Community of Cipatat District, Bandung Barat Regency)
}

\section{(Study of Health Literacy)}

\author{
Santi Susanti \\ Faculty of Communication \\ Sciences \\ Universitas Padjadjaran \\ Jatinangor-Sumedang, Indonesia \\ santisusanti2202@gmail.com
}

\author{
Fitri Perdana \\ Faculty of Communication \\ Sciences \\ Universitas Padjadjaran \\ Jatinangor-Sumedang, Indonesia \\ peet_lithuania79@ymail.com
}

\author{
Rangga Saptya M.P. \\ Faculty of Communication \\ Sciences \\ Universitas Padjadjaran \\ Jatinangor-Sumedang, Indonesia
}

\begin{abstract}
Plants have many benefits, one of which can be used as a medicine. Utilization of plants as a herbal mecidine has been done for a long time by the people of Indonesia, especially in the rural communities, among which are the residents of Cipatat District, Bandung Barat Regency. The provision of knowledge they have, being used by Cipatat residents for utilizing herbs as a cure for various disease they have. This research seeks to reveal the utilization of plants as a herbal medicine, how people acquire knowledge about the medicinal plants, and to what extent the literacy of Cipatat District communities of medicinal plants. This research was conducted at two locations, Gunung Masigit Village and Sumur Bandung Village. Through the qualitative-phenomenology method, by collecting data through in-depth interviews, observations and literature study, the results showed that the knowledge of the villagers of Gunung Masigit and Sumur Bandung village about medicinal plants is obtained through family environment and social environment and media. Herbal medicine are used for mild diseases. However, not all residents in the Gunung Masigit and Sumur Bandung Village know the benefits of medicinal herbs. Therefore, it is necessary for the local authorities and related institutions to participate in providing knowledge about the benefits of medicinal herbs as first aid and repromoting apotek hidup/living pharmacy through the planting of tanaman obat keluarga/family medicinal plants.
\end{abstract}

Keywords: medicinal plants, first aid, health literacy, family environment, social environment, living pharmacy.

\section{Introduction}

Indonesia's tropical forest is home to 80 percent of medicinal plants in the world. One thousand species of the 28,000 plant species grown, have been utilized as medicinal plants. (Pramono in Pribadi, 2009). In Indonesia, the use of herbs as a medicine has been done for along time and the knowledge of the utilization is passed on to future generations. The ingredients are taken from the root, leaves, flowers, fruit and wood (Suparni, 2012, p3).

Before the modern medicine develops, based on local wisdom, Indonesian people utilize the plants surrounding as a medicine. Although medicinal products have grown, still, there are people who maintaining local wisdom by utilizing medicinal plants as a cure for the illness. Producers of modern medicine then develop their products by producing herbal products derived from plants.

The use of herbal as a healer, can still be found in the community of Kabupaten Bandung Barat (KBB)/West Bandung regency. Almost all residents in 16 sub-districts in $\mathrm{KBB}$ are still using traditional medicine. One of them is in Cipatat District. The sub-district with $126.05 \mathrm{~km}^{2}$ of land area, is the most widespread area in KBB, spread into 12 villages consisting of Rajamandala Kulon, Ciptaharja, Cipatat, Citatah, Gunung Masigit, Cirawamekar, Nyalindung, Sumur Bandung, Kertamukti, Sarimukti,
Mandalasari, and Mandalawangi. Each village has a relatively varied land contour. (Badan Pusat Statistik Kabupaten Bandung Barat, 2015, p.1-3).

People in Gunung Masigit ${ }^{1}$ Village and Sumur Bandung $^{2}$ Village, two villages in District Cipatat, are still using plants as a medicine. Behind the knowledge they have, there are local wisdom values instilled by the ancestors regarding the use of these medicinal plants. Therefore, researchers are interested to conduct research on the use of medicinal plants by the community of Gunung Masigit and Sumur Bandung Village.

Before this research conducted, there have been previous studies that examined the efficacy of plants as a medicine. Two of these studies, namely Jalius and Muswita research from Jambi University entitled Eksplorasi Pengetahuan Lokal tentang Tumbuhan Obat di Suku Batin, Jambi (Local Knowledge Exploration of Medicinal Plants in Batin Tribe, Jambi and Kajian Etnobotani Tanaman Obat pada Masyarakat Desa Gunung Masigit, Kecamatan Cipatat, Kabupaten Bandung Barat. (The Ethnobotanical Study of Medicinal Plants by the

\footnotetext{
${ }^{1}$ http://repository.unpas.ac.id/12650/4/BAB\%20I.pdf. 28 Maret 2017

${ }^{2}$ http://repository.unpas.ac.id/12401/; 28 Maret 2017
} 
Community in Gunung Masigit Village, Cipatat SubDistrict, West Bandung Regency. ${ }^{3}$ )

In the first article, the research is aims to inventory the use of medicinal plants based on symptoms of the disease. Through survey method on 5 Battra in Tabir subdistrict, Merangin district, Jambi, the result found 86 types of medicinal plants used by Batin Tribe people for various treatment. The ability to use this herb is obtained from generation to generation. In general, medicinal plants are still obtained in the wild as on the riverbanks and forests, some medicinal plants have begun to be cultivated in home gardening.

In the second article, research inventory the types of medicinal plants used by the community of Gunung Masigit Village, West Bandung regency. The purpose of this research is to get information about medicinal plants used by the people of Gunung Masigit Village, as well as to know the benefits, types of plants and parts of plants that are used as medicine by the community of Gunung Masigit Village, West Bandung Regency.

In comparison with the two research above, this research focused on the individual experience of the villagers of Gunung Masigit and Sumur Bandung Village, as well as to reveal local wisdom values contained within and how to get the knowledge to utilize the medicinal plants.

\section{Literature Review \\ Local wisdom}

The term local wisdom was first introduced by HG. Quaritch Wales (in Budiwiyanto 2006) who calls local wisdom as a local genius which means a number of cultural traits shared by a society as a result of past experience. Yunus (2012) defines local wisdom as a culture that belongs to certain communities and places that are deemed to be able to survive in the face of globalization, because the local wisdom contains values that can be used as a means of building the character of the nation.

Suhartini (2009) states that local wisdom is a form of environmental wisdom that exists in community life in a place or area that refers to a particular locality and community. Fajarini (2014) interpreted local wisdom as a view of life and science and various life strategies that tangible activities undertaken by local communities in answering various problems in the fulfillment of their needs. The State (2011) states that local wisdom is not only about the knowledge or understanding of indigenous peoples about humanity and how good relations are among human beings, but also concerning knowledge, understanding and customs about humans, nature, and how are relations between all, knowledge is lived, practiced, taught, and passed down from one generation to another.

The local forms of local wisdom according to Aulia and Dharmawan (2010) can be values, norms, beliefs, and special rules. This diverse form has resulted in the functioning of local wisdom to vary. The functions of local wisdom include: (1) conservation and preservation of natural resources; (2) developing human resources; (3) development of culture and science; and (4) guidance on advice, beliefs, literature, and abstinence.

Some of the local wisdom definition basically has the same concept, where local wisdom is defined as a collection of knowledge in the form of values, norms, and specific rules developed, adhered to, and implemented by people somewhere and passed from generation to generation. Such knowledge is local, may differ from region to region, although it has the same meaning.

\section{Local Wisdom in Medicine Treatment, A Form of Health Literacy}

Local wisdom in the curement is related to the utilization of natural resources untuk fulfilled the human needs, in this case is medicinal plants. There is a learning process in it. The learning process, according to Hadi (2006), is needs from every community to

Regarding local wisdom, Hadi (2006) states that basically in every community, including traditional communities, there is a process to "be smart and knowledgeable". It relates to the desire to maintain and sustain life so that the citizens of the community will spontaneously think of ways to do and / or create something, including ways to make food and how to make the tools necessary to process natural resources for the sake of ensure the availability of food ingredients. In the process a very valuable discovery can occur unintentionally. They found that a certain type of plant can produce edible fruit after a certain way of processing; or certain leaves can heal them from abdominal pain, while other leaves can cure fever; or certain roots can heal the wound. Thus, they developed an original system of knowledge and technology called a local wisdom.

Traditional knowledge and local wisdom include, among others, plant-based or plant-based treatments. Hidayat (2005) in his book Ramuan tradisional ala 12 Etnis Indonesia tells that the plants have been used by humans since thousands of years ago to maintain health and treat various diseases. In the history of its development, noted prominent figures in the world of plant-based medicine, such as Hippocrates (460-370 BC), Dioscorides (40-80 BC), Galenus (131-200 AD), Avicenna (980-1037 AD), and Paracelsus (1493-1541 $\mathrm{AD})$.

In the book of Indonesian Tumbuhan Obat Indonesia: Penggunaan dan Khasiatnya, which compiled by Supriadi et al. (2001), it is stated that local knowledge in the use of natural plants / ingredients for treatment is generally owned by communities primarily located in the forest areas. Knowledge of medicinal plants, ranging from the introduction of plant species, the parts used, the way of processing to the efficacy of treatment, is a wealth of local knowledge of each ethnic 
in the local community. The traditional knowledge of medicinal properties of a plant for the cure of a disease is generally based on natural cues or animal behavior. For example, a heart-shaped leaf has a clue to cure liver disease; yellow plant parts such as turmeric and temulawak have clues to cure jaundice; sick animals that eat certain types of plants indicate that they are medicinal (Supriadi et al 2001: ix-xi).

Getting information is a literacy process undertaken by communities to get and to use information about medicinal plants. It is health literacy, an individual ability to get, process and understand the basic of health and needs of services to make the right decision of health (Zoellner, et al 2011)

\section{RESEARCH METHODS}

This research uses qualitative phenomenological methods, to collect and express the experience of the informants apply local wisdom in utilizing the plant as a medicine. Experience is described in accordance with the facts obtained in the field according to the delivery of informants.

The subject of this research is the people of Gunung Masigit and Sumur Bandung Village, which still utilize the plant as a medicine. The sample of this study was chosen based on the purpose or purposive sampling. This procedure is adopted to inform the selected informant according to the criteria relevant to the research problem (Bungin, 2011: 107).

\section{Data Collection Technique}

In this research, data collection is done through interviews, observation, and literature study. Data are sourced from community leaders and residents who still intensive use of medicinal plants to overcome various health complaints. Secondary data sources come from books, journals, magazines, and websites that discuss about the use of medicinal plants. The collected data was then analyzed using phenomenological data analysis done gradually, using models from Miles and Huberman.

\section{RESEARCH RESULT}

Based on interviews that have been done, it can be said that the behavior of the villagers of Gunung Masigit and Sumur Bandung Village in utilizing the plant as a medicine, carried out long ago and is a hereditary heritage of their ancestors. For residents of Cipatat subdistrict, especially in Gunung Masigit and Sumur Bandung, planting medicinal plants has become part of their life, mostly farmers. There are plants planted in the yard, there are also planted in the garden. For those grown in the garden, usually an agricultural commodity that can be sold to the market, such as ginger, turmeric,

${ }^{4}$ Zoellnerr, Jamie et al (2011). Health Literacy is Associated with Healthy Eating Inex(HEI) Score and Sugar Sweetened Beverage Intake: Finding fron the Rural Lower Mississippi Delta. laja, nutmeg, muncang, onion, lemongrass, onion, and so on. As for the planted in the yard of the house, usually used for the needs of the kitchen and for the treatment of first aid.

According to informants, the medicinal properties of plants are only temporary, as first aid. For further treatment that requires a handler more than just taking medicine, the patient is taken to the doctor or to the hospital.

Informant's knowledge about the efficacy of medicinal plants obtained through various sources. Some are obtained from generation to generation from the family's family, some are through interactions with neighbors / relatives or viewing television shows or books about the properties of plants for medicines.

In addition, residents also do nurseries to get the seeds of plants that they will plant in the garden. Although shifting land use has taken place, where much land for agriculture is used to grow cassava and bananas, however, there are still residents who grow plants, which selalin as vegetables can also be used as medicine, because the properties they contain.

Several kinds of plants and vegetables used as medicines by the villagers of Gunung Masigit and Sumur Bandung village include ginger, turmeric, laja, yellow coconut, green coconut leaf, jawer kotok, cat whiskers, pariah, samiloto, cassava leaves, papaya leaf, banana leaf, pumpkin, and others. Utilization for example for abdominal pain, hand knife cut, fever, toothache, jaundice, etc.

Knowledge of medicinal properties contained in plants were not kept alone, but transmitted also to the people around him. Various ways are done in transferring such knowledge. Some are done through direct interaction when there are people who complain of pain, some are done through counseling conducted in the neighborhood. The delivery of such knowledge is carried out by individuals who are elected as village cadres as well as heads of farmer groups. There is also by bringing agricultural extension from agriculture department or institution.

\section{CONCLUSION}

Based on the result of the research, it can be concluded that the villagers of Gunung Masigit and Sumur Bandung village, Cipatat sub-district, still maintain their ancestral heritage to grow medicinal plants, both medicinal plants and medicinal crops. Planting activities, in addition to medicinal plants, as well as for their own needs, for example for cooking, or for supplies if there are relatives or neighbors in need. The medicinal plant, used as a first aid if there are family members or citizens who suffered ill, because the location of pharmacies and hospitals far. Medicinal plants in the category of vegetables, also sold to meet the needs of the family economy. Herbal cultivation of medicinal plants should be developed again, because the seeds have started to rare and many people still do not 
understand about the benefits of medicinal plants. Many people still need counseling about good land management, so that the planting of medicinal plants and vegetables can be sustainable.

\section{REFERENCES}

Hadi, A.C Sungkana. Melestarikan Kearifan Masyarakat Tradisional (Indigenous Knowledge), Buletin Perpustakaan dan Informasi Bogor (Juni): 27-32, 2006

Hidayat, Syamsul. Ramuan tradisional ala 12 etnis Indonesia. Jakarta: Penebar Swadaya, 2005.

Iskandar, Johan. Ekologi Perladangan di Indonesia; Studi Kasus dari Daerah Baduy, Banten Selatan, Jawa Barat. Jakarta: Djambatan, 1992.

Jalius dan Muswita. Eksplorasi Pengetahuan Lokal tentang Tumbuhan Obat di Suku Batin, Jambi online-journal.unja.ac.id > Home > Vol 6, No 1 (2013) > Jalius. Diakses 25 Juni 2017

Kajian Etnobotani Tanaman Obat oleh Masyarakat Desa Sumur Bandung Kecamatan Cipatat Kabupaten Bandung Barat; http://repository.unpas.ac.id/12401/; 28 Maret 2017

Kajian Etnobotani Tumbuhan Obat oleh Masyarakat di Desa Gunung Masigit Kecamatan Cipatat Kabupaten Bandung Barat;
http://repository.unpas.ac.id/12650/4/BAB\%20I.pd f, 28 Maret 2017.

Permana, R. Cecep Eka. Tata ruang masyarakat Baduy.

Jakarta: Wedatama Widya Sastra, 2006.

Permana, R. Cecep Eka. Masyarakat Baduy dan Pengobatan Tradisional Berbasis Tanaman http://wacana.ui.ac.id/index.php/wjhi/article/downlo ad/145/134.

Purnomohadi, Srihartiningsih."Sistem Interaksi sosialekonomi dan pengelolaan sumber daya alam oleh masyarakat Badui di Desa Kanekes, Banten Selatan". Tesis Magister, Institut Pertanian Bogor, Bogor, 1990.

Sukandar E.Y. "Tren dan paradigma dunia farmasi, Industri-Klinik- Teknologi Kesehatan”. Orasi ilmiah Dies Natalis Institut Teknologi Bandung. (2006). http://itb.ac.id/focus/focus file/orasiilmiah-dies-45.pdf. diakses 25 Juni 2017.

Supriadi dkk. Tumbuhan Obat Indonesia; Penggunaan dan khasiatnya. Jakarta: Pustaka Populer Obor, 2001.

Zoellnerr, Jamie et al. Health Literacy is Associated with Healthy Eating Inex(HEI) Score and Sugar Sweetened Beverage Intake: Finding fron the Rural Lower Mississippi Delta, 2011. 